\title{
Pengaruh Model Pembelajaran Group Investigation (GI) Terhadap Kemampuan Pemecahan Masalah Matematis Siswa Pada Materi Peluang Kelas X MIPA
}

\author{
Alvia Hija ${ }^{1)}$, Resy Nirawati ${ }^{2)}$, Nindy Citroresmi Prihatiningtyas ${ }^{3)}$ \\ 1) Prodi Pendidikan Matematika STKIP Singkawang, Kalbar, Indonesia \\ E-mail:hijaalifya@ymail.com \\ 2) Program Studi Pendidikan Matematika STKIP Singkawang, Indonesia \\ E-mail:resynirawaty@gmail.com \\ 3) Program Studi Pendidikan Matematika STKIP Singkawang, Indonesia \\ E-mail: nindy.citroresmi@yahoo.com
}

\begin{abstract}
Abstrak. Penelitian ini bertujuan untuk mengetahui pengaruh model pembelajaran group investigation (GI) terhadap kemampuan pemecahan masalah matematis siswa pada materi peluang kelas X MIPA SMA Negeri 1 Singkawang. Penelitian ini merupakan penelitian true experiment dengan desain penelitian posttest only control group design. Populasi penelitian ini adalah siswa kelas X MIPA SMA Negeri 1 Singkawang, dan pengambilan dengan teknik simple random sampling. Kelas yang dijadikan sampel adalah kelas X MIPA 2 sebagai kelas eksperimen yang diberikan pembelajaran model group investigation (GI), dan X MIPA 3 sebagai kelas kontrol yang diberikan pembelajaran konvensional. Teknik analisis data yang digunakan dalam penelitian ini adalah uji-t dua sampel dan effect size. Hasil penelitian menunjukkan : (1) data penelitian dianalisis menggunakan uji-t dua sampel diperoleh t_hitung= 7,61, sedangkan t_tabel pada taraf signifikan 5\% dengan dk = 66 adalah 1,67 sehingga t_hitung> t_tabel. Hal ini menunjukkan bahwa kemampuan pemecahan masalah matematis siswa kelas yang diberikan model pembelajaran yang diberikan pembelajaran model GI lebih baik dibanding kelas yang diberikan pembelajaran konvensional. Dengan menggunakan uji effect size diperoleh nilai $\mathrm{ES}=1,305>0,8$ dengan kategori tinggi, sehingga menunjukkan bahwa model pembelajaran GI berpengaruh besar terhadap kemampuan pemecahan masalah matematis siswa pada materi peluang kelas X MIPA SMA Negeri 1 Singkawang; (2) hasil perhitungan aktivitas siswa diperoleh rata-rata sebesar $84,31 \%$ dengan kategori sangat aktif; (3)respon siswa terhadap model pembelajaran GI pada materi peluang sebesar $77,94 \%$ maka dapat dikategorikan kuat.
\end{abstract}

Kata Kunci: Model Pembelajaran Group investigation, Kemampuan Pemecahan Masalah Matematis

\section{PENDAHULUAN}

Matematika merupakan ilmu universal yang mendasari perkembangan teknologi modern, mempunyai peran penting dalam berbagai disiplin dan memajukan daya pikir manusia. Perkembangan pesat dibidang teknologi informasi dan komunikasi dewasa ini dilandasi oleh perkembangan matematika di bidang teori bilangan, aljabar, analisis, teori peluang dan matematika diskrit. Untuk menguasai dan menciptakan teknologi di masa depan diperlukan penguasaan matematika yang kuat sejak dini [8].

Secara umum menurut [12] No. 22 tahun 2006, pendidikan matematika bertujuan agar peserta didik memiliki kemampuan sebagai berikut.
1. Memahami konsep matematika, menjelaskan keterkaitan antar konsep dan mengaplikasikan konsep atau algoritma, secara luwes, akurat, efisien, dan tepat dalam pemecahan masalah.

2. Menggunakan penalaran pada pola dan sifat, melakukan menipulasi matematika dalam membuat generalisasi, penyusun bukti, atau menjelaskan gagasan dan pernyataan matematika.

3. Memecahkan masalah yang meliputi kemampuan memahami masalah, merancang model matematika, menyelesaikan model dan menafsirkan solusi yang diperoleh.

4. Mengomunikasikan gagasan dengan simbol, tabel, diagram, atau media lain untuk memperjelas keadaan atau masalah. 


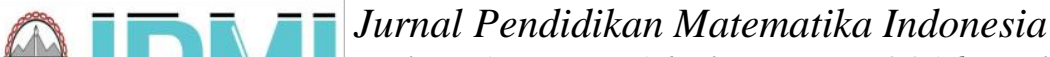

Memiliki sifat menghargai kegunaan matematika dalam kehidupan, yaitu memiliki rasa ingin tahu, perhatian, dan minat dalam mempelajari matematika, serta sikap ulet dan percaya diri dalam pemecahan masalah.

Tujuan pembelajaran matematika yang dirumuskan oleh National Countil of Teacher of Mathematic (NCTM) [11] adalah belajar untuk berkomunikasi (mathematical communication), belajar untuk bernalar (mathematical reasoning), belajar untuk memecahkan masalah (mathematical problem solving), belajar untuk mengaitkan ide (mathematical connection), dan pembentukan sikap positif terhadap matematika (positive attitude toward mathematics). Berdasarkan tujuantujuan tersebut, terlihat bahwa kemampuan pemecahan masalah matematis siswa merupakan tujuan penting dalam pembelajaran matematika.

Hasil PISA tahun 2012, Indonesia peringkat 64 dari 65 peserta, sedangkan di TIMSS (2011) Indonesia peringkat 36 dari 40 peserta. Dari hasil tersebut menunjukkan hasil yang buruk bagi siswa Indonesia. Berdasarkan laporan teknis PISA menunjukkan bahwa kurang dari $1 \%$ siswa Indonesia dapat menjawab pertanyaan-pertanyaan dalam situasi masalah yang kompleks yang memerlukan keterampilan pemodelan matematika, refleksi, konseptualisasi, generalisasi, dan penalaran. Ini berarti mereka hampir tidak mampu untuk menyelesaikan masalah yang memerlukan kemampuan penalaran dan pemecahan masalah. Selanjutnya TIMSS (2011), menunjukkan hanya $2 \%$ siswa Indonesia yang dapat bekerja dengan tingkat penalaran tinggi dan tidak ada yang dapat menyelesaikan masalah dengan beberapa informasi yang hilang. Hanya $43 \%$ dari siswa yang dapat menjawab pertanyaan pengetahuan tingkat rendah, sedangkan median Internasional dalam keterampilan pengetahuan adalah $75 \%$ (Wulandari, 2015;194).

Rendahnya kemampuan pemecahan masalah matematis siswa juga dialami oleh siswa SMA Negeri 1 Singkawang. berdasarkan observasi peneliti di SMA Negeri 1 Singkawang, guru mengajar masih dengan pembelajaran konvensional. Pembelajaran yang dilaksanakan masih menggunakan metode ceramah, tanya jawab dan pemberian tugas serta latihan soal sehingga siswa menjadi cepat bosan dan sulit untuk mengerti, yang akhirnya siswa menjadi sibuk sendiri dan tidak memperhatikan apa yang disampaikan oleh guru di depan kelas.

Pembelajaran yang masih bersifat konvensional mengakibatkan aktivitas siswa di kelas menjadi cenderung pasif. Siswa hanya menerima apa yang disampaikan oleh guru tanpa melakukan usaha untuk mencoba mencari dan mengolah kembali informasi terkait materi yang dipelajari, serta masih terdapat beberapa siswa yang terlihat mengantuk dan malas untuk mendengarkan dan mencatat hal-hal yang disampaikan guru selama proses pembelajaran berlangsung. Padahal disetiap proses pembelajaran, aktivitas siswa merupakan bagian yang sangat penting dan sangat diperlukan.

Berdasarkan hasil observasi dan wawancara terhadap beberapa siswa, sebagian besar siswa menyatakan bahwa pembelajaran matematika merupakan pembelajaran yang tidak menyenangkan dan kurang menyukai pembelajaran matematika dengan pembelajaran biasa (konvensional). Hal ini menunjukkan bahwa masih kurangnya respon siswa terhadap pembelajaran matematika di sekolah.

Model pembelajaran group investigation (GI) diharapkan mampu menjadi solusi untuk meningkatkan kemampuan pemecahan masalah matematis siswa khususnya pada materi peluang. Untuk itu peneliti tertarik mengadakan sebuah penelitian dibidang pendidikan matematika dengan judul "Pengaruh Model Pembelajaran Group investigation (GI) Terhadap Kemampuan Pemecahan Masalah Matematis Siswa Pada Materi Peluang Kelas $\mathrm{X}$ MIPA SMA Negeri 1 Singkawang".

Oleh karena itu tujuan dari penelitian ini adalah untuk mengetahui pengaruh model pembelajaraan group investigation (GI) terhadap kemampuan pemecahan matematis siswa kelas X MIPA SMA Negeri 1 Singkawang, aktivitas belajar siswa pada materi peluang dengan menggunakan model pembelajaran group investigation (GI), dan respon siswa pada materi peluang terhadap model pembelajaran group investigation (GI).

Group investigation (GI) adalah metode yang dikembangkan oleh Sharan-Sharan pada tahun 
1976. Model ini menekankan pada pilihan dan kontrol siswa daripada menerapkan teknik-teknik pengajaran di ruang kelas. Secara umum perencanaan pengorganisasian kelas dengan menggunakan model kooperatif GI adalah kelompok dibentuk oleh siswa itu sendiri dengan beranggotakan 2 sampai 6 orang, tiap kelompok memilih subtopik dari keseluruhan unit materi (pokok bahasan) yang akan diajarkan dan kemudian membuat atau menghasilkan laporan kelompok. Selanjutnya, setiap kelompok mempresentasikan atau memamerkan laporannya kepada seluruh kelas, untuk berbagi dan saling tukar informasi temuan mereka [14].

Adapun sintak model pembelajaran group investigation (GI) menurut [5] adalah sebagai berikut.

\section{Tahap Seleksi}

Para siswa memilih berbagai subtopik dari suatu bidang masalah umum yang biasanya digambarkan terlebih dahulu oleh guru, namun dalam penelitian ini guru membantu siswa dalam menentukan subtopik pokok bahasan. Selanjutnya siswa diorganisasikan ke dalam kelompokkelompok yang berorientasi pada tugas yang beranggotakan 2-6 orang dengan komposisi kelompok heterogen.

\section{Tahap Perencanaan Kerja Sama}

Para siswa dan guru merencanakan prosedur belajar khusus, tugas, dan tujuan umum yang konsisten dengan berbagai topik dan subtopik yang telah dipilih.

\section{Tahap Implementasi}

Para siswa melaksanakan rencana yan telah dirumuskan pada langkah sebelumnya. Pembelajaran harus melibatkan berbagai aktivitas dan keterampilan dengan variasi yang luas. Pada tahap ini guru harus mendorong para siswa untuk melakukan penelitian dengan memanfaatkan berbagai sumber. Guru secara terus menerus mengikuti kemajuan tiap kelompok dan memberikan bantuan jika diperlukan.

\section{Tahap Analisis dan Sintesis}

Para siswa menganalisis dan membuat sintesis atas berbagai informasi yang diperoleh pada langkah sebelumnya, lalu berusaha meringkasnya menjadi suatu penyajian yang menarik di depan kelas.

\section{Tahap Penyajian Hasil Akhir}

Semua kelompok menyajikan presentasinya atas topik-topik yang telah dipelajari agar semua siswa di dalam kelas saling terlibat dan mencapai suatu perspektif yang luas mengenai topik tertentu.

\section{Tahap Evaluasi}

Para siswa dan guru melakukan evaluasi mengenai kontribusi tiap kelompok terhadap pekerjaan kelas sebagai suatu keseluruhan. Evaluasi dapat dilakukan pada setiap siswa secara individual maupun kelompok, atau keduanya.

Asumsi yang digunakan sebagai acuan dalam pengembangan model pembelajaran group investigation (GI) yaitu untuk meningkatkan kemampuan kreativitas siswa dapat ditempuh melalui pengembangan proses kreatif menuju suatu kesadaran dan pengembangan alat bantu yang secara eksplisit mendukung kreativitas, komponen emosional lebih penting daripada intelektual,yang tak rasional lebih penting dari yang rasional dan untuk meningkatkan peluang keberhasilan dalam memecahkan suatu masalah harus lebih dahulu memahami komponen emosional dan irrasional [14].

Pemecahan masalah merupakan kompetensi strategi yang ditunjukkan siswa dalam memahami, memilih pendekatan dan strategi pemecahan, dan menyelesaikan model untuk menyelesaikan masalah [9]. Menurut [2] pemecahan masalah merupakan penyelesaian untuk menjembatani jurang "apa yang diketahui dan apa yang dipertanyakan". Kemampuan pemecahan masalah ditunjang oleh kemampuan menguasai sejumlah konsep dan prinsip. Kemampuan pemecahan masalah banyak menunjang kreativitas seseorang, yaitu kemampuan menciptakan ide baru, baik yang bersifat asli ciptaan sendiri maupun merupakan suatu modifikasi (perubahan) dari berbagai ide yang telah ada sebelumnya. Hal ini ditegaskan oleh NCTM (dalam [19]) bahwa para siswa harus belajar matematika dengan pemahaman, secara aktif membangun pengetahuan baru dari pengalaman dan pengetahuan sebelumnya. Pembelajaran yang bertujuan untuk membentuk kemampuan pemecahan masalah lebih menekankan pada penyajian materi pembelajaran dalam bentuk penyajian masalah yang menuntun proses penemuan masalah. 
Hudojo menyatakan bahwa pemecahan masalah merupakan suatu hal yang sangat essensial dalam pengajaran matematika. Hal ini disebabkan karena (1) siswa menjadi terampil menyeleksi informasi yang relevan, kemudian menganalisanya dan akhirnya meneliti isinya; (2) kepuasan intelektual akan timbul dari dalam; (3) potensi intelektual siswa meningkat [6].

John Dewey (dalam [18]) mengemukakan langkah-langkah dalam pemecahan masalah sebagai berikut.

a. Merasakan adanya kesulitan atau yang menuntut pemecahan

b. Merumuskan dan membatasi masalah sebagai dasar untuk mencari fakta dalam upaya menemukan pemecahannya.

c. Mengajukan suatu rumusan kesimpulan sementara terhadap pemecahan masalah (hipotesis) yang akan diuji kebenarannya berdasarkan fakta atau argumentasi yang nalar.

d. Menguji hipotesis yang diajukan dengan suatu bukti yang dapat menjadi dasar untuk menolak atau menerima kebenaran hipotesis yang dibuat.

e. Merumuskan kesimpulan dari hasil pengujian hipotesis.

Dengan langkah-langkah pemecahan masalah ini, proses pembelajaran di kelas dapat membiasakan siswa menghadapi dan memecahkan masalah secara terampil dan dapat diterapkan dalam kehidupan sehari-hari.

Adapun indikator yang menunjukkan kemampuan pemecahan masalah matematis siswa [9] antara lain adalah:

a. Menunjukkan pemahaman masalah

b. Mengorganisasikan data dan memilih informasi yang relevan dalam pemecahan masalah

c. Menyajikan masalah secara matematik dalam berbagai bentuk

d. Memilih pendekatan dan metode pemecahan masalah secara tepat

e. Mengembangkan strategi pemecahan masalah

f. Membuat dan menafsirkan model matematika dari suatu masalah

g. Menyelesaikan masalah yang tidak rutin

Indikator pemecahan masalah indikator pemecahan masalah menurut Polya yaitu memahami masalah, menyusun rencana pemecahan masalah, melaksanakan rencana penyelesaian masalah, dan melakukan pengecekan kembali [7].

Dari berbagai indikator pemecahan masalah yang telah diuraikan, peneliti menyimpulkan bahwa terdapat empat indikator kemampuan pemecahan masalah matematis penting dalam penelitian ini yaitu, (1) memahami masalah; (2) rencana pemecahan masalah; (3) melaksanakan rencana penyelesaian masalah; (4) melakukan pengecekan kembali.

Aktivitas adalah keseluruhan kegiatan siswa yang dilakukan selama proses pembelajaran yang sudah berlangsung [10]. Rohani menjelaskan bahwa belajar yang berhasil mesti melalui berbagai macam aktivitas, baik aktivitas fisik maupun psikis. Aktivitas fisik ialah siswa giat aktif dengan anggot badan, membuat sesuatu, bermain, ataupun bekerja, ia tidak hanya duduk, mendengarkan, melihat atau hanya pasif. Siswa yang memiliki aktivitas psikis adalah jika daya jiwanya bekerja sebanyak-banyaknya atau hanya berfungsi dalam rangka pembelajaran saat siswa aktif jasmaninya dengan sendirinya ia juga aktif jiwanya, begitu pula sebaliknya [1].

Paul B. Diedrich membuat satu daftar yang berisi 177 macam kegiatan siswa yang antara lain dapat digolongkan dalam beberapa klasifikasi antara lain: (1) Visual activities seperti membaca, memperhatikan gambar demonstrasi, percobaan dan pekerjaan orang lain; (2) Oral activities seperti menyatakan, merumuskan, bertanya, member saran, mengeluarkan pendapat, mengadakan wawancara, diskusi dan interupsi; (3) Listening activities seperti mendengarkan uraian, percakapan, diskusi, music dan pidato;(4) Writing activities seperti menulis cerita, karangan, laporan, angket, menyalin; (5) Drawing activities seperti menggambar, membuat grafik, peta dan diagram; (6) Motor activities seperti melakukan percobaan, membuat kontruksi, model mereparasi, bermain, berkebun dan beternak; (7) Mental activities seperti menanggapi, mengingat, memecahkan soal, menganalisis, melihat hubungan dan mengambil keputusan, dan (8) Emotional activities seperti menaruh minat, merasa bosan, gembira, bersemangat, bergairah, berani, tenang dan gugup [15]. 
Dari beberapa definisi tersebut, jelas bahwa dalam kegiatan belajar mengajar subjek atau siswa harus aktif berbuat. Dengan kata lain, dalam belajar sangat diperlukan aktivitas. Tanpa aktivitas, proses belajar tidak mungkin berlangsung dengan baik. Aktivitas belajar siswa yang dimaksud dalam penelitian ini adalah aktivitas siswa selama mengikuti proses pembelajaran dengan model group investigation (GI) yaitu visual activities, oral activities, listening activities, writing activities, mental activities, dan emotional activities.

Respon siswa adalah penerimaan, tanggapan dan aktivitas yang diberikan siswa selama pembelajaran [20]. Respon merupakan perwujudan dari sikap-sikap daerah afektif, yaitu hal-hal yang berhubungan dengan sikap sebagai perwujudan minat, motivasi, kecemasan, apresiasi perasaan, penyesuaian diri, dan bakat [17]. Respon terbentuk dari proses rangsangan atau pemberian perlakuan atau sebab yang berujung pada hasil reaksi dan akibat dari proses ransangan [13]. Respon siswa dapat berupa tanggapan yang bersifat positif maupun negatif. Respon siswa terhadap pembelajaran dapat diupayakan dengan menarik perhatian siswa dalam kegiatan pembelajaran yang dilakukan.

Respon siswa yang dimaksudkan dalam penelitian ini adalah tanggapan siswa terhadap sejumlah pernyataan pada angket yang dapat mengukur minat dan sikap siswa terhadap pembelajaran matematika dengan model pembelajaran group investigation (GI) pada materi peluang.

Pada penelitian ini penulis mengambil materi pokok peluang dengan sub materi pokok peluang suatu kejadian yang ada di kelas X. Kompetensi dasar yang terdapat pada materi peluang adalah menyajikan hasil penerapan konsep peluang untuk menjelaskan berbagai objek nyata melalui percobaan menggunakan frekuensi relatif melalui model pembelajaran group investigation (GI). Peluang adalah suatu cara untuk menyatakan kesempatan terjadinya suatu peristiwa. Berdasarkan definisi empirik, peluang didefinisikan sebagai nilai frekuensi relatif munculnya peristiwa jika banyaknya percobaan relatif besar (tak hingga).
Frekuensi relatif dari suatu hasil yang mungkin terjadi dalam suatu percobaan adalah perbandingan banyaknya hasil yang terjadi dalam suatu percobaan dengan banyaknya percobaan dilakukan. Frekuensi relatif dari kejadian A dapat dituliskan:

$F_{F}(A)=\frac{k(A)}{n}$ dengan $k$ adalah banyaknya hasil yang terjadi dan $n$ adalah banyaknya percobaan.

Ruang sampel atau ruang contoh merupakan himpunan dari semua hasil yang mungkin pada suatu hasil percobaan simbol dari ruang sampel S. Titik-titik sampel merupakan anggota-anggota dari ruang sampel. Sebagai contoh pada percobaan sekali melempar dadu yang bersisi enam, maka ruang sampelnya adalah $S=\{1,2,3,4,5,6\}$, banyaknya runag sampel adalah $\mathrm{n}(\mathrm{S})=6$. Kejadian merupakan himpunan bagian dari ruang sampel, terdapat dua jenis kejadian yaitu kejadian sederhana dan kejadian majemuk. Kejadian sederhana yaitu kejadian yang hanya memiliki satu titik sampel sedangkan kejadian majemuk adalah suatu kejadian yang mempunyai titik sampel lebih dari satu. Berdasarkan definisi klasik peluang suatu percobaan misalnya terdapat kejadian A dapat terjadi dalam $\mathrm{k}$ cara dari keseluruhan $\mathrm{n}$ cara yang mempunyai kemungkinan sama untuk terjadi. Peluang kejadian A dapat dituliskan.

$$
\mathrm{P}(\mathrm{A})=\frac{k}{n}
$$

Jika S merupakan ruang sampel dari suatu percobaan dengan setiap anggota $\mathrm{S}$ memiliki peluang yang sama untuk muncul. Kemudian A adalah suatu kejadian dalam ruang sampel $\mathrm{S}$, peluang kejadian A dirumuskan dengan.

$$
\mathrm{P}(\mathrm{A})=\frac{n(A)}{n(S)}
$$

\section{METODE}

Jenis penelitian ini adalah jenis penelitian kuantitatif dengan metode eksperimen. Penelitian ini menggunakan penelitian true eksperimental dengan posttest-only control design. Populasi dalam penelitian ini adalah seluruh siswa kelas $\mathrm{X}$ MIPA SMA Negeri 1 Singkawang yang terbagi menjadi 4 kelas yaitu kelas X MIPA 1, X MIPA 2, $X$ MIPA 3, dan X MIPA 4 dengan jumlah 138 siswa. Teknik pengambilan sampel yang 
digunakan adalah teknik probability sampling yaitu simple random sampling.

Probability sampling adalah teknik pengambilan sampel yang memberi peluang yang sama bagi setiap unsur (anggota) populasi untuk dipilih menjadi anggota sampel. Simple random sampling yaitu pengambilan anggota sampel dari populasi yang dilakukan secara acak tanpa memperhatikan strata yang ada dalam populasi itu, cara demikian dilakukan bila anggota populasi dianggap homogen [16]. Sampel yang diambil dalam penelitian ini terdiri dari 2 kelas, satu kelas sebagai kelas eksperimen yaitu kelas X MIPA 2 yang berjumlah 34 siswa dan satu kelas sebagai kelas kontrol yaitu kelas $\mathrm{X}$ MIPA 3 yang berjumlah 34 siswa.

Penelitian ini terdiri dari dua variabel yaitu variabel bebas dan variabel terikat. Variabel bebas dalam penelitian ini adalah model pembelajaran yang akan diterapkan yaitu model pembelajaran group investigation (GI) dan pembelajaran konvensional. Variabel terikat dalam penelitian ini adalah kemampuan pemecahan masalah matematis, aktivitas dan respon siswa kelas X MIPA SMA Negeri 1 Singkawang tahun pelajaran 2015/2016 pada materi peluang.

Teknik pengumpulan data yang digunakan dalam penelitian ini adalah adalah (a) Teknik tes; (b) Teknik observasi; (c) Teknik komunikasi tak langsung. Untuk keperluan data dalam penelitian ini digunakan instrumen (a) Tes kemampuan pemecahan masalah matematis siswa; (b) Lembar pengamatan aktivitas belajar siswa; (c) Angket respon siswa.

Untuk memperoleh soal tes yang baik maka soal tes tersebut harus dinilai validitas, realiabilitas, tingkat kesukaran dan daya pembeda. Berdasarkan hasil uji coba soal hasil pengukuran validitas, realiabilitas, tingkat kesukaran dan daya pembeda tersebut diuraikan sebagai berikut.

Tabel 1

Rekapitulasi Validitas, Tingkat Kesukaran, Daya Pembeda dan Reliabilitas Soal

\begin{tabular}{cccccc}
\hline No & $\begin{array}{c}\text { Interpretasi Interpretasi Interpretasi Reliabi Kesimpulan } \\
\text { Validitas }\end{array}$ & $\begin{array}{c}\text { Ingkat } \\
\text { Tingaran } \\
\text { Kesukaran }\end{array}$ & $\begin{array}{c}\text { Daya } \\
\text { Pembeda }\end{array}$ & \\
\hline 1a & 0,58 & 0,75 & 0,22 & & Soal Dipakai \\
1b & 0,69 & 0,69 & 0,33 & 0,56 & Soal Dipakai \\
1c & 0,47 & 0,58 & 0,28 & & Soal Dipakai \\
1d & 0,41 & 0,61 & 0,22 & & Soal Dipakai
\end{tabular}

\begin{tabular}{lllll}
$2 \mathrm{a}$ & 0,24 & 0,58 & 0,22 & Soal Dipakai \\
2b & 0,57 & 0,70 & 0,22 & Soal Dipakai \\
2c & 0,53 & 0,64 & 0,22 & Soal Dipakai \\
2d & 0,59 & 0,67 & 0,33 & Soal Dipakai \\
\hline
\end{tabular}

Berdasarkan hasil analisis keseluruhan pada Tabel 1 terhadap hasil uji coba tes kemampuan pemecahan masalah matematis siswa yang dilaksanakan di SMA Negeri 3 Singkawang maka dapat disimpulkan bahwa soal tersebut layak dipakai sebagai acuan untuk mengukur kemampuan pemecahan masalah matematis siswa. Dalam penelitian ini teknik analisis data yang digunakan adalah sebagai berikut. (1) Untuk menjawab sub masalah pertama, mengetahui kemampuan pemecahan masalah matematis siswa antara yang diberikan model pembelajaran group investigation dan pembelajaran konvensional, maka digunakan statistik yang sesuai. Adapun langkah-langkahnya yaitu melakukan uji normalitas data kedua kelas, melakukan uji homogenitas varians kedua kelas, melakukan uji-t dua sampel independen, dan menghitung nilai effect size. (2) Untuk menjawab sub masalah kedua, yaitu untuk mengetahui aktivitas belajar siswa selama proses pembelajaran dengan model group investigation (GI). Untuk menganalisa penilaian aktivitas siswa, langkah-langkahnya adalah sebagai berikut. (a) Menghitung persentase setiap indikator aktivitas pembelajaran yang dilakukan; (b) Menghitung persentase total setiap tahap dari indikator-indikator yang ada; (c) Menghitung rata-rata persentase dari tiga pengamat. (3) Untuk menjawab sub masalah ketiga, yaitu untuk mengetahui respon siswa setelah diterapkan model pembelajaran group investigation (GI), maka hasil angket respon siswa dianalisis dengan menggunakan statistik deskriptif dalam bentuk persentase yang dikelompokkan ke dalam beberapa kategori dan kriteria penilaian.

\section{HASIL DAN PEMBAHASAN}

HASIL

Penilaian kemampuan pemecahan masalah matematis siswa dinilai dari skor rata-rata tiap indikator kemampuan pemecahan masalah matematis siswa dan nilai rata-rata kemampuan pemecahan masalah matematis siswa. Berdasarkan 
analisis hasil posttest kemampuan pemecahan masalah matematis siswa pada kelas kontrol dan eksperimen rata-rata skor untuk setiap indikator kemampuan pemecahan masalah matematis siswa dapat dilihat pada tabel 2 sebagai berikut.

Tabel 2

Skor Rata-rata Siswa untuk Setiap Indikator Kemampuan Pemecahan Masalah

\begin{tabular}{lcccc}
\hline \multicolumn{1}{c}{ Indikator } & \multicolumn{2}{c}{ Skor Rata-rata } & \multicolumn{2}{c}{ Persentase } \\
\cline { 2 - 5 } & Eksperimen Kontrol Eksperimen & Kontrol \\
Memahami & 3,55 & 3,16 & $89,97 \%$ & $79,04 \%$ \\
$\begin{array}{l}\text { Masalah } \\
\text { Membuat Rencana }\end{array}$ & 2,40 & 2,25 & $79,90 \%$ & $75,50 \%$ \\
$\begin{array}{l}\text { Penyelesaian } \\
\text { Melaksanakan }\end{array}$ & 3,00 & 2,28 & $74,63 \%$ & $56,99 \%$ \\
$\begin{array}{l}\text { Rencana } \\
\text { Penyelesaian }\end{array}$ & 1,57 & 1,22 & $78,68 \%$ & $61,03 \%$ \\
$\begin{array}{l}\text { Melakukan } \\
\text { Pengecekan }\end{array}$ & & & & \\
\hline
\end{tabular}

Dari Tabel 2 rata-rata kemampuan pemecahan masalah matematis siswa (posttest) kelas eksperimen lebih tinggi dibandingkan rata-rata kemampuan pemecahan masalah matematis siswa kelas kontrol.

Pengujian normalitas menggunakan uji ChiKuadrat. Hasil uji normalitas data posttest disajikan dalam tabel berikut.

Tabel 3. Uji Normalitas Data Posttest

\begin{tabular}{ccc}
\hline Kelas Penelitian & $x^{2}$ hitung & $x^{2}$ tabel \\
\hline Eksperimen & 9,89 & 11,07 \\
Kontrol & 4,72 & 11,07 \\
\hline
\end{tabular}

Pengujian dilakukan pada taraf signifikan 0,05 . Dari tabel 3 diperoleh $X_{\text {hitung }}^{2}<X_{\text {tabel }}^{2}$ sehingga dapat disimpulkan bahwa data posttest berdistribusi normal. Dari hasil perhitungan $F_{\text {hitung }}$ diperoleh nilai $F_{\text {hitung }}=1,17$, dan harga $F_{\text {tabel }}$ yang diperoleh sebesar 1,76 . Oleh karena itu dapat disimpulkan $F_{\text {hitung }}<F_{\text {tabel }}$ yaitu $1,17<1,76$ maka kelas eksperimen dan kelas kontrol setelah diberikan perlakuan mempunyai varians yang sama (homogen). Berdasarkan uji normalitas dan uji homogenitas, diperoleh bahwa data posttest baik kelas eksperimen maupun kelas kontrol berdistribusi normal dan mempunyai varians yang sama (homogen). Maka untuk untuk menguji kesamaan rata-rata kedua kelas selanjutnya dapat digunakan dengan uji-t dua sampel. Dari hasil perhitungan diperoleh bahwa $t_{\text {hitung }}>t_{\text {tabel }}$ yaitu $7,61>1,67$. Dengan demikian Ho ditolak dan Ha diterima dengan taraf signifikan $5 \%$ atau 0,05 sehingga dapat disimpulkan bahwa terdapat perbedaan yang signifikan antara kelas eksperimen dan kelas kontrol yaitu kemampuan pemecahan masalah matematis siswa kelas ekperimen lebih tinggi dibanding kemampuan pemecahan masalah matematis siswa kelas kontrol.

Dari perhitungan diperoleh Effect Size sebesar 1,305 > 0,8 dengan kategori tinggi. Hal ini menunjukkan bahwa pengaruh variabel yang diteliti pada kelas eksperimen lebih besar dibanding kelas kontrol. Sehingga dapat disimpulkan bahwa model pembelajaran group investigation (GI) berpengaruh besar terhadap kemampuan pemecahan masalah matematis siswa pada materi peluang.Secara deskriptif rata-rata kemampuan pemecahan masalah matematis siswa (posttest) kelas eksperimen lebih tinggi dibandingkan rata-rata kemampuan pemecahan masalah matematis siswa kelas kontrol. Rata-rata posttest kelas eksperimen adalah 80,35 sedangkan rata-rata posttest kelas kontrol adalah 68,94. Perbedaan kemampuan pemecahan masalah matematis siswa tersebut diikuti pula dengan adanya perbedaan yang ditimbulkan oleh masingmasing perlakuan terhadap kemampuan pemecahan masalah matematis siswa. Siswa yang diberi perlakuan dengan menggunakan model pembelajaran group investigation (GI) mendapat kontribusi lebih baik daripada siswa yang diberi perlakuan dengan pembelajaran konvensional.

Dari pengujian kesaaman dua rata-rata antara kelas eksperimen dan kelas kontrol dengan menggunakan uji t pooled varians dengan $\alpha=5 \%$ diperoleh bahwa nilai $t_{\text {hitung }}>t_{\text {tabel }}$, yaitu $7,61>1,67$, maka Ho ditolak dan Ha diterima sehingga dapat disimpulkan bahwa terdapat perbedaan yang signifikan antara rata-rata kemampuan pemecahan masalah matematis siswa yang diberi pelakuan dengan model pembelajaran group investigation (GI) dan kemampuan pemecahan masalah matematis siswa yang diberi pelakuan dengan pembelajaran konvensional. Sedangkan untuk pengujian besar pengaruh model pembelajaran group investigation (GI) terhadap kemampuan pemecahan masalah matematis siswa 
pada materi peluang, dilakukan pengujian dengan menggunakan effect size, diperoleh bahwa nilai ES (effect size) sebesar 1,305 dengan kategori tinggi. Sehingga dapat disimpulkan pengaruh model pembelajaran group investigation (GI) terhadap kemampuan pemecahan masalah matematis siswa pada materi peluang di SMA Negeri 1 Singkawang lebih besar dari pada pengaruh model pembelajaran konvensional. Hasil ini sejalan dengan penelitian yang dilakukan oleh Musriadi (2013) yang menyimpulkan bahwa kemampuan pemecahan masalah matematis dan self-concept siswa yang memperoleh model pembelajaran matematika tipe group investigation (GI) lebih baik daripada siswa yang memperoleh pembelajaran konvensional.

Lembar observasi digunakan untuk mengetahui aktivitas siswa selama mengikuti pembelajaran dengan menggunakan model pembelajaran group investigation (GI). Pengamatan yang dilakukan selama dua kali pertemuan yang dilakukan oleh 3 orang observer, secara ringkas dinyatakan dalam Tabel 4 sebagai berikut.

Tabel 4. Persentase Pengamatan Aktivitas Siswa Pertemuan Pertama dan

\begin{tabular}{|c|c|c|c|c|}
\hline \multicolumn{5}{|c|}{ Kedua } \\
\hline No & $\begin{array}{c}\text { Kategori } \\
\text { Pengamatan }\end{array}$ & $\begin{array}{c}\text { Pertemuan } \\
1\end{array}$ & $\begin{array}{c}\text { Pertemuan } \\
2\end{array}$ & $\begin{array}{c}\text { Rata- } \\
\text { rata }\end{array}$ \\
\hline 1 & Visual activities & $82,35 \%$ & $89,71 \%$ & \\
\hline 2 & Oral activities & $66,18 \%$ & $65,93 \%$ & \\
\hline 3 & $\begin{array}{l}\text { Listening } \\
\text { activities }\end{array}$ & $87,75 \%$ & $85,29 \%$ & \\
\hline 4 & $\begin{array}{l}\text { Writing } \\
\text { activities }\end{array}$ & $96,32 \%$ & $94,77 \%$ & $84,31 \%$ \\
\hline 5 & Mental activities & $93,63 \%$ & $93,63 \%$ & \\
\hline 6 & $\begin{array}{c}\text { Emotional } \\
\text { activities }\end{array}$ & $79,80 \%$ & $75,00 \%$ & \\
\hline & Jumlah & $504,56 \%$ & $504,33 \%$ & \\
\hline & Rata-rata & 84,35 & $84,27 \%$ & \\
\hline & Kriteria & & Sangat Aktif & \\
\hline
\end{tabular}

Berdasarkan Tabel 4 diperoleh rata-rata dari enam kategori pengamatan, dua kali pertemuan dan tiga orang observer yaitu sebesar $84,31 \%$. Hal ini menunjukkan bahwa aktivitas siswa selama pembelajaran berlangsung berada pada kategori sangat aktif. Dengan demikian dapat disimpulkan bahwa siswa menjadi aktif pada pembelajaran materi peluang dengan menggunakan model pembelajaran group investigation (GI). Hasil ini sejalan dengan penelitian yang dilakukan oleh [4] yang menyimpulkan bahwa aktivitas siswa dengan menggunakan model pembelajaran group investigation (GI) berjalan dengan baik. Hal ini menunjukkan bahwa model pembelajaran group investigation (GI) berpengaruh positif terhadap aktivitas belajar siswa.

Respon siswa diperoleh melalui penyebaran angket setelah kegiatan pembelajaran menggunakan model pembelajaran group investigation (GI). Angket diberikan kepada siswa bertujuan untuk mengetahui tanggapan siswa terhadap sejumlah pernyataan pada angket baik yang bersifat positif maupun negatif.

Tabel 5. Angket Respon Siswa

\begin{tabular}{|c|c|c|c|c|c|c|c|c|}
\hline \multirow{2}{*}{$\begin{array}{c}\text { Jumlah siswa } \\
\text { yang memilih } \\
\text { kategori }\end{array}$} & \multicolumn{5}{|c|}{ Jawaban } & \multirow{2}{*}{$\begin{array}{c}\text { Jumlah } \\
\text { Skor }\end{array}$} & \multirow[b]{2}{*}{$\%$} & \multirow[b]{2}{*}{ Kriteris } \\
\hline & SS & $\mathbf{S}$ & $\mathbf{N}$ & TS & STS & & & \\
\hline $\begin{array}{c}\text { Pernyataan } \\
\text { positif }\end{array}$ & 56 & 213 & 56 & 14 & 1 & 1329 & 78,18 & Kuat \\
\hline $\begin{array}{c}\text { Pernyataan } \\
\text { negatif }\end{array}$ & 2 & 13 & 56 & 220 & 49 & 1329 & 77,71 & Kuat \\
\hline
\end{tabular}

Dari Tabel 5 diperoleh rata-rata persentase sebesar $78,18 \%$ pada pernyataan positif dengan kategori kuat dan $77,71 \%$ pada pernyataan negatif dengan kategori kuat. Dengan demikian dapat disimpulkan bahwa respon siswa pada materi peluang dengan model pembelajaran group investigation (GI) adalah positif. Hasil ini sejalan dengan penelitian yang dilakukan oleh [4] yang menyimpulkan bahwa siswa memberikan respon yang positif terhadap model pembelajaran kooperatif tipe group investigation (GI) dengan kriteria sangat baik.

\section{KESIMPULAN DAN SARAN}

\section{KESIMPULAN}

Berdasarkan Berdasarkan analisis data hasil penelitian yang dilakukan dan pembahasan secara umum dapat disimpulkan bahwa 


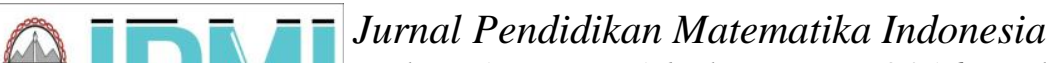 \\ Volum 1 Nomor 1 bulan Maret 2016. Halaman 25-33 \\ p-ISSN: 2477-5967 e-ISSN: 2477-8443}

1. Pengaruh model pembelajaran group investigation (GI) terhadap kemampuan pemecahan masalah matematis siswa pada materi peluang di SMA Negeri 1 Singkawang lebih besar dari pada pengaruh model pembelajaran konvensional.

2. Aktivitas siswa tergolong sangat aktif dengan model pembelajaran group investigation (GI) pada materi peluang di kelas X MIPA SMA Negeri 1 Singkawang.

3. Respon siswa terhadap model pembelajaran group investigation (GI) pada materi peluang adalah positif.

SARAN

Berdasarkan hasil penelitian, saran dalam penelitian ini adalah sebagai berikut.

1. Bagi siswa untuk menambah semangat untuk lebih aktif dalam belajar, berpikir positif bahwa matematika bukanlah pelajaran yang yang sulit dan berusaha untuk menyenangi matematika.

2. Bagi guru mata pelajaran dapat menjadikan model pembelajaran group investigation (GI) sebagai alternatif model belajar yang relevan selain pembelajaran konvensional sehingga dapat membantu siswa dalam menyelesaiankan soal-soal yang berkaitan dengan kemampuan pemecahan masalah matematis siswa dan materi peluang.

3. Bagi peneliti, penelitian ini sangat bermanfaat dalam menambah wawasan dan ilmu pengetahuan untuk bekal masa depan sehingga dapat menjadi lebih baik lagi, karena melalui penelitian ini peneliti mendapatkan pengalaman tentang model pembelajaran yang baik .

4. Kepada peneliti yang ingin melakukan penelitian seperti ini diharapkan mampu untuk menyempurnakan kelemahan-kelemahan penelitian ini agar diperoleh hasil yang lebih baik dan memaksimalkan penggunaan model pembelajaran group investigation dalam meningkatkan kemampuan pemecahan masalah matematis siswa.

\section{DAFTAR PUSTAKA}

[1] Fariyah. 2013. Penerapan Model Pembelajaran Kooperatif Group Investigation (GI) untuk Meningkatkan Keaktifan dan Hasil Belajar Siswa Kelas X Pada Materi Inflasi di SMA Negeri 1 Candiroto Temanggung Tahun Pelajaran 2012/2013. Skripsi. Universitas Negeri Semarang. Tidak Dipublikasikan

[2] Hamzah, Ali dan Muhlisrarini. 2013. Perencanaan dan Strategi Pembelajaran Matematika. Jakarta : PT Raja Grafindo Persada.

[3] 2014. Evaluasi Pembelajaran Matematika. Jakarta Raja Grafindo Persada.

[4] Hidayat, Asep Taufik. 2016. Pengaruh Model Pembelajaran Kooperatif Tipe Group Investigation Terhadap Kemampuan Berpikir Kreatif Siswa Pada Materi Bangun datar. Skripsi. Universitas Pendidikan Indonesia. Bandung. Tidak Dipublikasikan.

[5] Huda, Miftahul.2013. Model-model Pengajaran dan Pembelajaran : Isu-isu Metodis dan Paradigmatik. Yogyakarta : Pustaka Pelajar.

[6] Husna dkk.2013.Peningkatan Kemampuan Pemecahan Masalah dan Komunikasi Matematis Siswa Sekolah Menengah Pertama Melalui Model Pembelajaran Kooperatif TipeThink Pair Share (TPS). Jurnal Peluang, Volume 1, Nomor 2, April 2013, ISSN :2302-5158.

[7] Husna, Raudatul dkk. 2013.Peningkatan Kemampuan Pemecahan Masalah dan Komunikasi Matematik Melalui Pendekatan Matematika Realistik pada Siswa SMP Kelas VII Langsa. Jurnal Pendidikan Matematika PARADIKMA, Vol 6. Nomor 2.

[8] Ibrahim dan Suparni. 2012. Pembelajaran Matematika Teori dan Aplikasinya. Yogyakarta : Suka Press.

[9] Jihad, Asep dan Haris, Abdul. 2008. Evaluasi Pembelajaran Yogyakarta : Multi Presindo.

[10] Kusumaningrum, Anggita Dwijayanti. 2013. Peningkatan Aktivitas dan Hasil Belajar Siswa Kelas IV Pada Materi Koperasi Melalui Model Pembelajaran Kooperatif Tipe Student Teams Achivement Devision di SD Negeri Tegal Sari 8 Kota Tegal.Skripsi.Universitas Negeri Semarang.Tidak Dipublikasikan.

[11] Musriandi, Riki. 2013. MoESel Pembelajaran Matematika Tipe

[12] NCTM. 2000. Principles and Standard for School Mathematics. Reston : United States of America.

[13] Permendiknas. 2006. Peraturan Menteri Pendidikan Nasional Nomor 22 Tahun 2006 Tentang Standar Isi Sekolah Menengah Pertama. Jakarta: Depdiknas.

[14] Puspita, Anggi Ria. 2011. Respon Siswa SMP Negeri 3 Kelapa Bangka Belitung Terhadap Film Laskar Pelangi. Skripsi. Universitas Islam Negeri Syarif Hidayatullah. Jakarta. Tidak Dipublikasikan.

[15] Rusman.2012. Model-model Pembelajaran : Mengembangkan Profesionalisme Guru. Jakarta : PT Raja Grafindo Persada.

[16] Sardiman. 2014. Interaksi \& Motivasi Belajar Mengajar. Jakarta : PT Raja Grafindo Persada

[17] Sugiyono. 2015. Metode Penelitian Pendidikan : Pendekatan Kuantitatif, Kualitatif, dan R\&D. Bandung : Alfabeta.

[18] Sukasno. 2006. Evaluasi Pembelajaran Matematika. Lubuk Linggau : STKIP-PGRI Lubuk Linggau.

[19] Sumiati dan Asra.2007. Metode Pembelajaran. Bandung : CV Wacana Prima.

[20] Walle, John A. Van de. 2008. Matematika Sekolah Dasar dan Menengah : Pengembangan Pengajaran. Jakarta : Airlangga.

[21] Zulhemi. 2009. Penilaian Psikomotor dan Respon Siswa dalam Pembelajaran Sains Fisika melalui Penerapan Penemuan Terbimbing di SMP Negeri 20 Pekan Baru Jurnal Geliga Sains, Vol 3(2),8-132009, ISSN : 1978-502X 